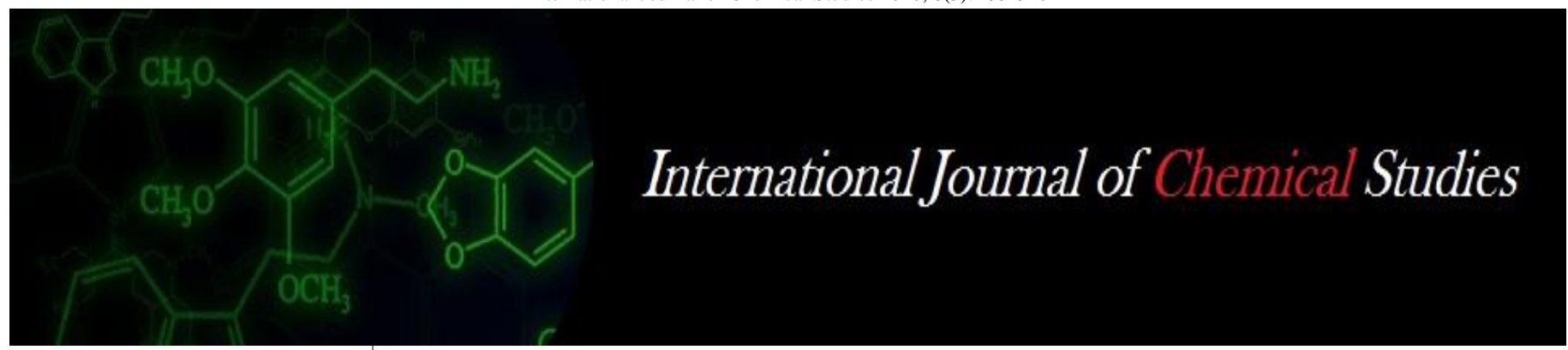

P-ISSN: 2349-8528

E-ISSN: 2321-4902

www.chemijournal.com

IJCS 2020; 8(5): 499-510

(C) 2020 IJCS

Received: 20-07-2020

Accepted: 21-08-2020

\section{VP Santhi}

Horticultural College and

Research Institute for Women,

Tamil Nadu Agricultural

University, Navalur Kuttapattu,

Trichy, Tamil Nadu, India

\section{N Nireshkumar}

Grapes Research Station

Tamil Nadu Agricultural

University, Theni, Tamil Nadu,

India

\section{Vasugi}

Indian Institute of Horticultural

Research-ICAR, Bengaluru,

Karnataka, India

\section{S Parthiban}

Horticultural College and

Research Institute for Women,

Tamil Nadu Agricultural

University, Navalur Kuttapattu,

Trichy, Tamil Nadu, India

\section{P Masilamani}

(1) Horticultural College and Research Institute for Women,

Tamil Nadu Agricultural

University, Navalur Kuttapattu,

Trichy, Tamil Nadu, India

(2) Anbil Dharmalingam

Agricultural College and

Research Institute, Tamil Nadu

Agricultural University, Trichy,

Tamil Nadu, India
Corresponding Author:

\section{VP Santhi}

Horticultural College and

Research Institute for Women,

Tamil Nadu Agricultural

University, Navalur Kuttapattu,

Trichy, Tamil Nadu, India

\section{Role of rootstocks to mitigate biotic and abiotic stresses in tropical and subtropical fruit crops: A review}

\author{
VP Santhi, N Nireshkumar, C Vasugi, S Parthiban and P Masilamani
}

DOI: https://doi.org/10.22271/chemi.2020.v8.i5g.10348

\begin{abstract}
Fruit cultivation not only plays a crucial role in nutritional security but also offers employment opportunities, higher income and productivity to the farming community. Biotic and abiotic stresses are the most ominous factors in fruit production, which reduces the growth and productivity thereby resulting in an impact on global fruit production and availability. Biotic and abiotic stresses, including drought, extremes of temperature, various pest and diseases, salinity in soil and water are problems which are becoming acute. There is an urgent need to improve biotic and abiotic stress tolerance in fruit crops by using traditional breeding and biotechnology approaches like gene silencing and transgrafting. Nowadays, the virus resistance transgenic rootstocks are developed by using small interfering RNA s (silencing RNA) method. Rootstock breeding in fruit crops is a great challenge due to difficulty in identification of tolerant or resistance rootstock for various purposes. In this paper, we have discussed the various biotic and abiotic stresses, resistance mechanisms, and available resistant rootstocks so far as well as challenges in rootstock breeding which can be helpful to manage stress conditions in fruit cultivation. Further research is needed to develop the resistance rootstocks by using modern rootstock breeding methods with various biotechnological approaches.
\end{abstract}

Keywords: Biotic and abiotic stress, rootstock breeding, resistance mechanism, gene silencing, silencing RNA and Trans grafting

\section{Introduction}

During recent decades, climate change, various biotic and abiotic stresses are the serious challenges being faced worldwide which influences the performance of fruit crops and showed a negative impact on global fruit production and availability. The reduction of yield due to poor utilization of land areas, poor adaptability under adverse biotic and abiotic stress condition, lack of awareness about the adoption of improved hi-tech horticultural practices, continuing reduction in the availability of cultivable area, low yielding varieties and inadequate technological up-gradation (Tsering dolkar et al., 2018) ${ }^{[97]}$. The stresses like biotic and abiotic play crucial roles in the growth, survival, adaptability, productivity and yield of fruit crops (Redondo-Gomez, 2013) ${ }^{[83]}$. Biotic and abiotic stresses, including drought, extremes of temperature, various pest and diseases, salinity in soil and water are problems which are becoming acute (Flowers, 2004) ${ }^{[37]}$.

Due to the limited availability of cultivable area and even that is not suitable for cultivation, fruits are cultivated under unfavourable soil and stress condition to meet the huge market demand for fruits. The rootstocks play a major role in fruit cultivation by influencing canopy architecture, adaptability to adverse climatic condition, nutritional uptake, flowering, yield and fruit quality. Besides, rootstocks can also be used for high-density planting (HDP) and build up resistance to biotic and abiotic stresses such as pest and diseases incidence, drought, salinity, nematode infections, thermal stress and nutritional stress (Reddy et al., 2003) ${ }^{[82]}$. Among the abiotic stresses, salinity is one of the major ones that affect growth and yield of plants in arid and semi-arid areas throughout the world (Chelli i-Chaabouni et al., 2010) ${ }^{[22]}$. Most of the plants produce osmoprotectant metabolites such as proline, glycine-betaine and soluble sugars to protect the cells against the damaging effects from salt stress. Halophytes plants which can survive and reproduce even under high salt concentration with $200 \mathrm{mM}$ $\mathrm{NaCl}$, Galophytes plants are cannot survive in salinity condition and eventually die. 
However, most of the major fruit crops belong to this category. To alleviate these environmental stresses, adaptability and lower productivity only a few scientific approaches are available and one of the best concepts is the use of certain tolerant rootstocks in fruit cultivation which are capable of reducing the effect of external stresses. The rootstock yields a high degree of compatibility and resistant to major biotic (pests and diseases) and abiotic stresses (light, heat, salinity, drought, waterlogging and temperature tolerance, etc.) (Fig.1). Further, rootstock enhances nutrient uptake and improves flowering and fruit set by imparting disease and pest tolerance.

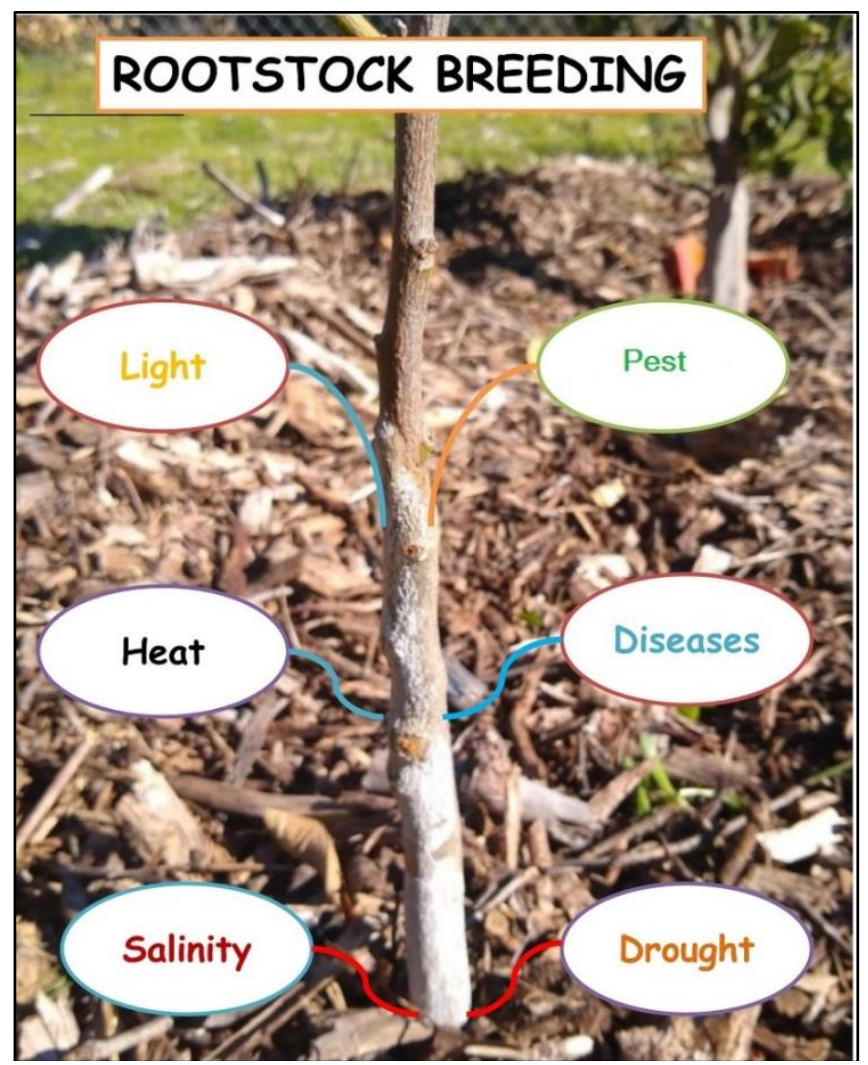

Fig 1: Objectives of Rootstock breeding

\section{Rootstock breeding}

Rootstock breeding in fruits is a great challenge to scientists because identification of tolerant or resistance rootstock is difficult. Rootstock breeding and selection is a new discipline and selection of seedling and clonal rootstocks substantially began in the 19th century. In rootstock breeding, germplasm conservation plays a major role because it is a source of resistant and used for various breeding activities. Resistance rootstock can be developed through conventional breeding methods. In the case of conventional rootstock breeding, development of rootstock takes a long time to get the desired output and maintenance of rootstock population under field condition is difficult. To overcome these difficulties, a modern biotechnological approach such as molecular assisted selection is used for easier screening of resistant rootstock. Vos and Shoeman (2000) ${ }^{[100]}$ studied the selection of guava wilt resistant rootstock seedlings against Penicillium vermoesenii under in-vitro condition. The results revealed that out of 30,000 guava seedlings only three showed $100 \%$ tolerance to guava wilt disease. Different types of markers involved in rootstock breeding that accelerate the selection process. In citrus, marker-assisted selection applied for rootstock breeding for identifying various biotic and abiotic stress tolerance rootstocks at an early stage. One of the marker assistant selections in citrus conducted by Xiang Xu et al., (2010) ${ }^{[104]}$ and its selection is based on gene locus "Tyr 1 " controlling citrus nematode resistance. Somatic hybridization and protoplast fusions are used for creating intergeneric hybrids.

RNA silencing is one of the gene expression mechanisms that regulates endogenous gene expression and gives defense against viruses. In transgenic plants, RNA silencing has been transmitted between rootstock and scions through grafting. Virus resistance transgenic rootstocks were developed by using small interfering RNA $s$ (siRNA s) mediated gene silencing method. By this way, siRNA s transported from the transgenic rootstocks that may enhance the virus resistance in non-transgenic scions. RNA interference (RNAi) is widely used for virus-resistant transgenic plants production. Plant parasitic nematodes are controlled by insecticides/ nematicides but they are harmful to the environment, while other methods like crop rotation and resistant cultivars also very limited. In this case, RNA interference (RNAi) is applied to create resistance plants against devastating parasites. Marker-assisted selection in rootstock breeding can be used to evaluate resistance traits and new rootstocks with resistance to multiple diseases. The use of molecular markers in grapes has been explored for Pierce's disease resistance, dagger nematode resistance and powdery mildew resistance (Dalbo et al., 2001) [28]. In citrus rootstock breeding, seven Random Amplification of Polymorphic DNA were found linked to the CTV resistance gene by bulked sergeant analysis (Mestre et al., 1997) [67]. Nowadays, the applications of molecular markers are most common and some markers like randomly amplified polymorphic DNA (RAPD), Inter Simple Sequence Repeat (Bagheri et al., 2019) [9] fluorescently labelled sequence tag and simple sequence repeat (EST-SSR) are commonly helpful in rootstock breeding. Even in the citrus selection, randomly amplified polymorphic DNA (RAPD) analysis has been used for distinguishing nuclear embryos from zygotic (Bastianel et al., 1998) ${ }^{[11]}$.

\section{Rootstocks resistance mechanism}

The rootstock is a major contributor to the performance and longevity of the tree. Rootstock can determine the tree size, yield, fruit quality and also tolerance to biotic and abiotic stresses. Plants have built up resistance to various biotic and abiotic stress conditions by some types of resistance mechanisms (Fig.2). In general, plants have three types of resistance mechanism viz., morphological, biochemical and physiological. Morphological resistance is influenced by root characteristics like root structure, length, width and root hairs. Biochemical resistance offered by creating favourable condition i.e osmotic environment by which overcoming from stress conditions. Physiological resistance is created by the synthesis of toxins, tannins and phenolic acids etc (Fig.3). 


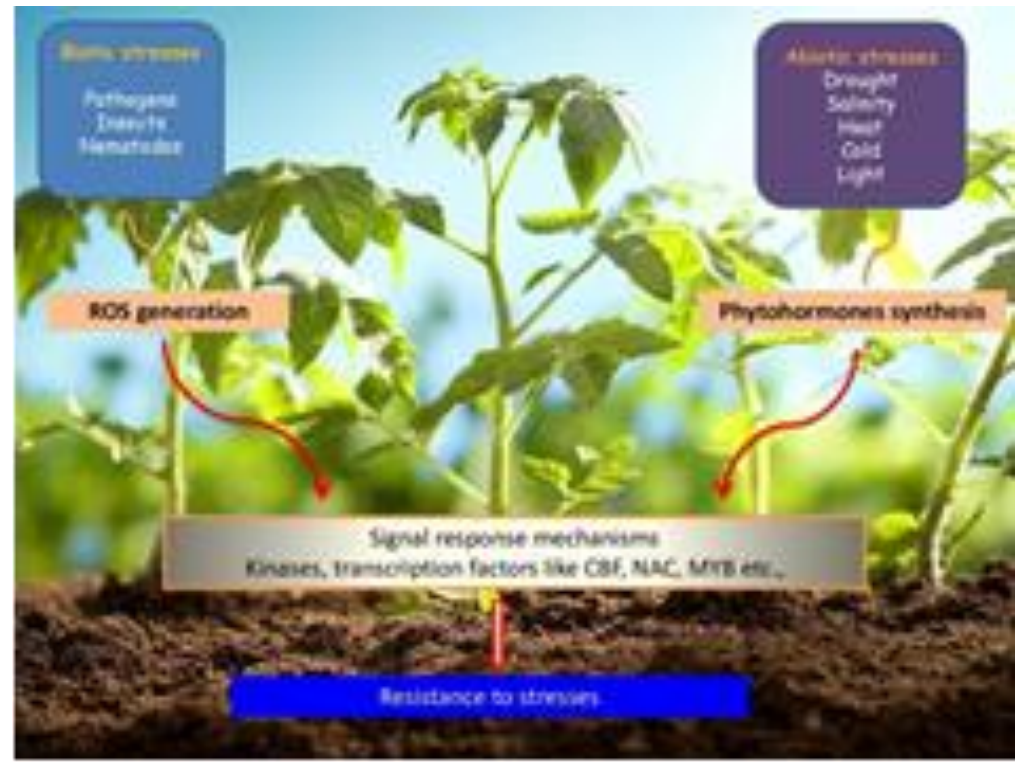

Fig 2: Rootstock resistance mechanism

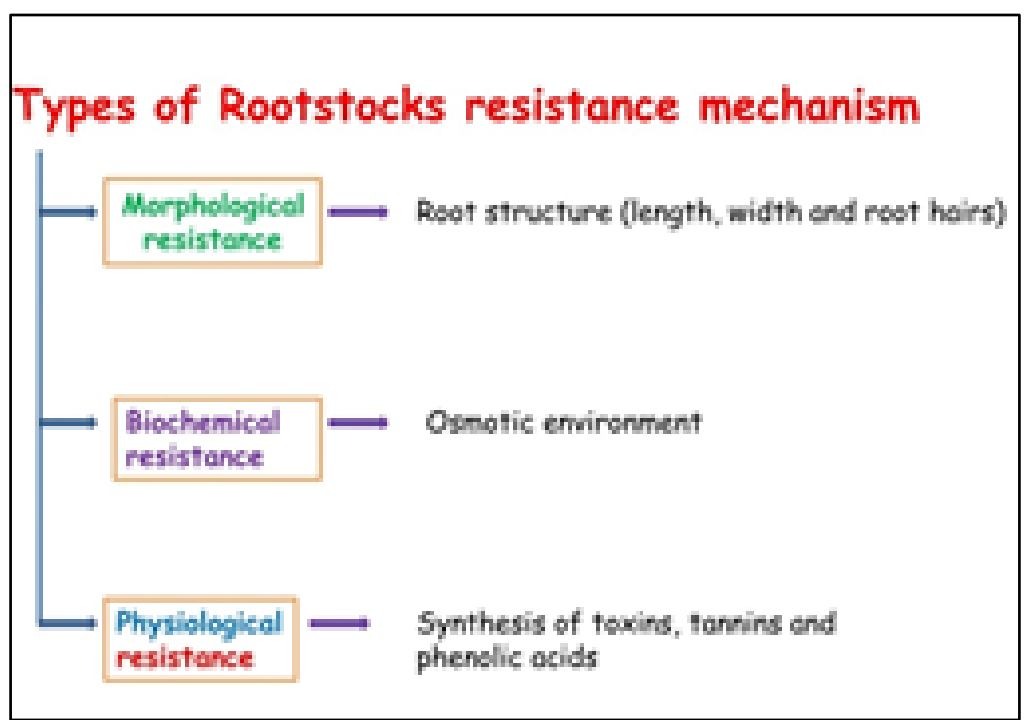

Fig 3: Types of rootstock resistance mechanism

\section{Resistance mechanism to biotic stress}

In grapes, the hypersensitive reaction of leaves and roots are linked and they showed resistance to phylloxera disease (Schmid et al., 2001) ${ }^{[87]}$. Nematodes are a major problem which feeds the roots and causes damage to the root system. The nematode infected root system showed the reduction of water and nutrient uptake in the plant. Some rootstocks show resistance to nematodes by the mechanism of roots inhibits the entry of female nematodes thereby avoiding further multiplication of nematodes. Sathisha et al., (2007) ${ }^{[86]}$ found that rootstocks like $110 \mathrm{R}, 1103 \mathrm{P}, 99 \mathrm{R}$ and B2-56 were showed the higher content of total phenols, flavonoids, proline and total protein. The higher phenolic content in rootstocks may help in reducing the disease incidence.

\section{Resistance mechanism to abiotic stress}

Plants react at the physiological, biochemical and genetic level to tolerate various adverse climatic conditions like drought, salinity, light and temperature. The mango rootstock 13-1 has the capacity to less salt retention than retranslocation in soil. Under the saline condition, accumulation of excess of $\mathrm{Na}^{+}$and $\mathrm{CL}^{-}$ions can cause ion toxicities, inhibit growth and reduces the yield. So the selection of rootstock for salinity tolerance that restricts these ions will serve under saline condition. Plants showed resistance/tolerance to salinity by activating different mechanisms viz., salt avoidance, salt excretion, salt exclusion, osmotic adjustment and antioxidant defensive system. In case of drought stress, rootstocks produce abscisic acid which may involve the water conservation processes by stomatal closure. Some grapes rootstock like dogridge, $110 \mathrm{R}, \mathrm{B} 2-56$ and salt creek recorded the highest water use efficiency and relative water content at single leaf level thereby rootstocks overcoming the drought condition. Pavlousek (2011) ${ }^{[75]}$ studied the evaluation of rootstock for drought tolerance and results revealed that Borner (Vitis cinerea) rootstock is suitable for drought condition. Water stress has a significant effect on shoot length and chlorophyll content. Some rootstocks are used for dwarfing purpose and that also be more drought-resistant. Moreover, increased drought resistance of rootstocks may show a negative effect on yield. Serra et al., (2014) ${ }^{[88]}$ found that the increased drought resistance in grapes often reduces yield while increasing water use efficiency. In this review, a clear overview of abiotic and biotic stress in mango, guava, grapes, loquat, pomegranate, avocado and citrus fruits are discussed. 


\section{Mango (Mangifera indica L.)}

Mango, also known as 'King of fruits' is one of the commercial fruit crops cultivated throughout the tropical and subtropical countries for their immense value. Rootstocks have been used for the successful cultivation of mango in problematic soil, environmental stress condition, to improve the adaptability and in the adoption of high-density planting. Attempts were made to standardize the rootstocks including polyembryonic varieties for vigour management, salinity, water stress tolerance and ultimately improve yield and quality of mango. To alleviate these problems by using salttolerant polyembryonic mango cultivar ' $13 / 3$ ' is being evaluated as salt rootstock for 'Kesar' mango at the Reliance mango plantation at Jamnagar (Gunjate, 2009) ${ }^{[45]}$. The nanoparticles viz., nano-zinc oxide $(\mathrm{nZnO})$ and nano-silicon (nSi) effectively used to improve the salinity resistance mechanism and productivity in Ewais mango (Elsheery et al., 2020) [35]. According to Rossetto et al., (1996) ${ }^{[85]}$ polyembryonic rootstocks like IAC 103 Macoca and IAC 108 Pindorama showed resistant to the fungi $C$. fimbriata. IAC 103 Macoca and IAC 107 Tiete polyembryonic rootstocks are used as resistance against fruit fly incidence. Ribeiro et al., (1993) ${ }^{\left[{ }^{84]}\right.}$ reported that selection of mango rootstock resistant to wilt Ceratocystis fimbriata with two strains by inoculation of pathogen pure culture through soil watering which revealed that mango rootstocks like Carabao, Manga d Agua and Pico were immune to the race FITO 334-1 and highly resistant to FITO 4905. Mango trees on '13-1' rootstocks showed excellent performance on soil containing $20 \%$ lime, three other cultivars on ' $13-1$ ' rootstock showed good development on sandy soil with 10- $20 \%$ lime and irrigation water containing 250 ppm. In Florida, polyembryonic rootstocks like turpentine are used for propagation (Zuazo et al., 2006) [106]. In Australia, 'Kensington' seedlings are used as rootstock. Duran et al., (2003) ${ }^{[32]}$ found that Gomera-1 used as salt-tolerant which can restrict the uptake and transport of $\mathrm{Cl}$ - and $\mathrm{Na}+$ ions from the root system to the above-ground parts of the tree. Under the saline condition, mango root growth and function can be restricted by a high $\mathrm{Na}+\mathrm{Ca} 2+$ ratio (Fig.4). Cultivar stem in which the $\mathrm{Na}+/ \mathrm{Ca} 2+$ ratio was higher than in the rootstock

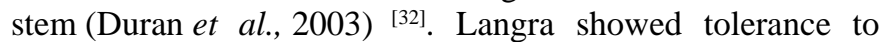
salinity by the mechanism of less electrolyte leakage and which improves the relative water content, transpiration rate, stomatal conductance Ahmed et al., (2020) ${ }^{[3]}$. Kannan et al., (2004) studied that sixteen (16) putative of endophytic bacteria were isolated from sodicity tolerant polyembryonic mango rootstock of GPL-3 and ML-4 and evaluate tolerant strains by pot culture of rice under the saline condition of $\mathrm{pH}$ 9.35 and EC 4.2. The results have shown that strain CSR-M16 increased root and shoot length of rice followed by CSRM-8, CSR-M-9 and CSR-M-6 and these four isolates were found to be tolerant to high salt concentration $(2.5 \mathrm{M} \mathrm{NaCl})$ and also showed higher uptake of sodium when cultured under in-vitro conditions at this concentration. Cultivation of Kesar mango in the Saurashtra region of Gujarat in adverse growing conditions viz., salinity, drought and heat stress which affects growth and yield. To alleviate these adverse effects by using of Kesar grafted on salt-tolerant rootstocks (Balan, 2017) ${ }^{[10]}$. Luvaha et al., (2007) ${ }^{[65]}$ reported that water stress which reduces the gas exchange and chlorophyll content slightly increased in the rootstock. Limited work has been done in rootstock breeding in mango and more research studies are needed in this study area. The quality of rootstocks is determined by compatibility, resistance to stresses, nutrient uptake, economic life and wider adaptability (Fig.5).

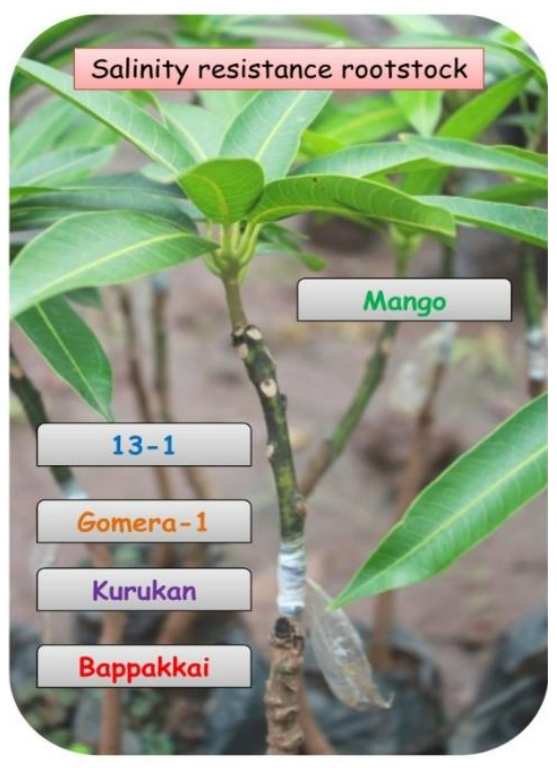

Fig 4: Salinity resistance rootstock

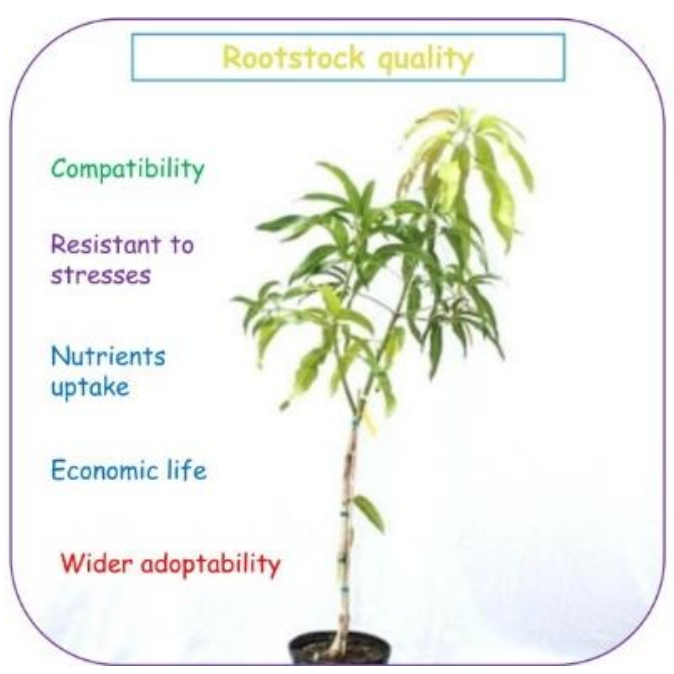

Fig 5: Quality of Rootstock

\section{Guava (Psidium guajava L.)}

Guava exceeds most of the tropical and subtropical fruit trees in adaptability and productivity due to its chilling, drought, and salinity tolerance (Yadava, 1996; Bezerra et al., 2018) ${ }^{[105,}$ ${ }^{12]}$. The exogenous foliar application of putrescine has been used to provide better salt tolerance to guava seedlings (Ghalati et al., 2020). A variety with in-built resistance to the biotic and abiotic stress besides high yielding capacity of good quality fruit is lacking. As stated by Usman et al., (2013) ${ }^{[98]}$, recombination breeding between varieties and wild species is one of the major approaches of guava improvement. Use of wild species for guava crop improvement to introduce certain gene(s) for specific traits viz., tolerance/ resistance to biotic stresses like wilt and nematode, abiotic stresses like salt and drought tolerance, dwarf stature, the precocious bearing has been one of the approaches. The exploitation of wild species requires extensive knowledge about flowering behaviour and its compatibility with the cultivated varieties. Psidium cattleianum is a small shrub, can adapt to many soil types and is a quite cold resistant (Normand, 1994) ${ }^{[73]}$, tolerates shade (Cronk and Fuller 1995) ${ }^{[24]}$, has good salt tolerance and flowers and early seed maturity (Cronk and 
Fuller, 1995) ${ }^{[24]}$, the type of apomixis reported as disploporic origin (Souza-Pérez and Speroni (2017) ${ }^{[93]}$. Inter-specific hybridization has been attempted to develop rootstocks resistant to guava wilt. During the rainy season bagging of guava fruits at marble stage significantly reduced the biotic incidence like a fruit fly, anthracnose and bird damage Sharma et al., $2020^{[91] .}$

Higher levels of tolerance or resistance to root-knot nematodes are present in wild Psidium species such as $P$. friedrichsthalianum, $P$. cattleianum or $P$. arayan (Lozano et al., 2008) [63]. Utilization of wild species for guava crop improvement has been one of the ways to introduce certain gene(s) for specific traits viz., dwarf stature, biotic and abiotic stress. The exploitation of wild species requires extensive knowledge of crossability barriers and fertility of the hybrids. Interspecific hybridization has been attempted by several workers. The interspecific hybridization was carried out between $P$. molle and $P$. guajava and the interspecific hybrids developed are graft compatible with commercial varieties of $P$. guajava. They are being evaluated for wilt resistance (Anon. 2016-17; Negi and Rajan, 2007) ${ }^{[8,70]}$ under various agro-climatic zones.

In recent years, root-knot nematodes (Meloidogyne spp.) are emerging as a major threat to guava cultivation in India. The primary source of infection is through infected potting mixture which is used for raising the planting materials. Nematodes start killing the plants from nursery stage to orchards which are in the establishing stage/ young orchards. In India, $M$. enterlobii, $M$. incognita, $M$. javanicaand $M$. indica are the major root-knot nematodes recorded in guava (Hodda, et al., 2012) ${ }^{[49]}$. Nematode infection sites in the roots also predispose the roots to easy entry of soil-borne pathogenic fungi like Fusarium spp which makes the disease complex and is rapidly spreading major guava growing belts in India, which needs the most attention.

According to Freitas et al., (2014) [39], $P$. friedrichsthalianum (Costa Rican wild guava) and $P$. cattleianumvar. lucidum (lemon guava) presented resistance or immunity to root knot nematode ( $M$. enterolobii) and Psidium guineense (Costa et al., 2012) ${ }^{[23]}$ showed tolerance to the nematode. In general, guava is moderately tolerant to salinity ( 4.7 to $8.0 \mathrm{dsm}$ ) however, its response to salinity depends upon the species/genotypes and its growth stages. It tolerates $\mathrm{NaCl}$ level up to $30 \mathrm{mM}$ without serious growth depressions (Ali-Dinar et al., 1999; Ebert et al., 2002) $[4,33]$. The red guava is reported to possess a better salt tolerance compared to white guava (Ali-Dinar et al., 1999) ${ }^{[4]}$. Use of rootstocks has gained prominence in improving its degree of tolerance to abiotic stress like salinity. In the evaluation of guava rootstocks ('Crioula', 'Paluma' and 'Ogawa') for salt tolerance, by employing five levels of irrigation water salinity $(0.6,1.2,1.8,2.4$ and $3.0 \mathrm{dS} \mathrm{m}-1)$ in the initial development stage revealed that the increased salinity restricts the seedling emergence, growth and phytomass accumulation, and the most drastic effects occur at levels higher than $1.8 \mathrm{dS} \mathrm{m}-1$. The results revealed that cultivar 'Crioula' was more tolerant to salinity (Souza et al., 2016) ${ }^{[92]}$.

\section{Grapes (Vitis vinifera)}

In viticulture, the rootstocks play a vital role to overcome the adverse effects of salinity, drought, pest and disease resistance and also to modify the scion physiology/ morphology in terms of vine vigour, fruitfulness, bunches and berry characters etc. Li et al., $2019^{[60]}$ suggested that grafting is one of the ways to create resistance to various biotic and abiotic stresses by grafting the grapevines onto resistant rootstocks. The use of acid tolerant rootstocks, such as ' $\mathrm{SO} 4$ ' and '3309C' was highly recommended for acid soils. Salinity is an important problem in grapevine cultivation include decreased the availability of soil-water and toxicity to vines due to accumulation of $\mathrm{Cl}^{-}$and $\mathrm{Na}^{+}$(Ibacache et al., 2020) ${ }^{[51]}$. Salt tolerance has been mainly associated with the ability of different cultivars, rootstocks or their combinations to accumulate or restrict $\mathrm{Na}^{+}$and $\mathrm{Cl}^{-}$in leaves or shoot. Walker et al., (2004) ${ }^{[101]}$ found that selection of salt tolerant rootstock for grapes cultivar Sultana and it is grafted on various rootstocks viz., Ramsey, 1103 Paulsen, J17-69 and 4 hybrids (designated R1, R2, R3 and R4). Among the various rootstocks, Ramsey and $\mathrm{R} 2$ showed high to moderate $\mathrm{Cl}^{-}$ exclusion ability and suitable for salt tolerance in Sultana grapevine. But R2 rootstock is sensitive to Phylloxera disease. According to Mehanna et al., (2010) [66] the Salt creek rootstock recorded the higher shoot length, leaf area, leaf number, root length, root $\mathrm{Ca}$ content and had a significant reduction in stomatal diffusion resistance compared to 1103 Paulsen.

Under the saline condition, application of uni-sal or humic substance can alleviate the adverse effect of salinity on grape rootstock. Guo et al., (2018) ${ }^{[46]}$ concluded that A15 rootstock had strong alkali resistance by secreting organic acids mainly oxalic acid and proton pump (VvPMA3) may play an important role in $\mathrm{NaHCO}_{3}$ stress through promotion of organic acid secretion in the roots to reduce $\mathrm{NaHCO}_{3}$ stress. Sharma et al., (2011) ${ }^{[00]}$ reported that Thompson seedless vines grafted on Dog Ridge and salt creek do not withstand continual exposure to saline irrigation $(\leq 6.5 \mathrm{dS} \mathrm{m}-1)$ compared to those on $\mathrm{B} 2-56$ and $1613 \mathrm{C}$ with the latter two being effective in maintaining a lower $\mathrm{Na}+\mathrm{K}+$ ratio and thus lesser injury to the shoot system. Flame seedless grapevines grafted on Paulson $1103 \mathrm{P}$ rootstock can minimize the cell wall degradation enzyme activities of berry pedicles and alleviated the loss of berries due to berry shattering during storage period Banna and Loay (2019) ${ }^{[34]}$. Dikilitas et al., 2020 stated that foliar spray of exogenous proline applications showed more tolerant to environmental stresses.

Drought is one of the limiting factors and ultimately reduces the yield and quality. Some rootstocks already found tolerant to water stress is controlling and adjusting the water supply to shoot transpiration demand during stress condition. Both rootstock and scion genotypes can confer to the drought adaptability influencing respectively the capacity of water extraction from the soil and the sensitivity of the stomatal control. Rootstock 140Ru was showed high adaptation to water deficit condition (Tarmontini et al., 2013) [95]. 110R rootstock tolerates the drought stress by rapid reestablishment of root elongation and water uptake capacity Cuneo et al., (2020) [27]. Nimbolkar et al., (2016) [71]. reported that grapevine rootstocks that increased the efficiency of stomatal closure by chemical (ABA) and hydraulic (aquaporins) signalling that act as a major tolerance to water stress. Hochberg et al., (2013) ${ }^{[48]}$. reported that grapevine rootstocks that increased the efficiency of stomatal closure by Abscisic acid (ABA) and hydraulic (aquaporins) signalling that act as a major tolerance to water stress. Lu jinxing et al., (2012) ${ }^{[64]}$ studied that cold hardiness in six grapes varieties resulted in relative conductivity significantly increased with the lowering of the temperature. The activity of the POD decreased as the temperature dropped down, while superoxide dismutase and catalase increased first and then declined. Among the six 
rootstocks, Beta rootstock showed the highest tolerance to the cold.

Some rootstock showed resistance/tolerance to various pest and diseases. Cabernet Sauvignon grafted with 039-16 rootstock had the smallest degree of grapevine fanleaf virus (GFV) and 039-16 rootstock used for resistance to GFV. Ramsey and 1103 Paulsen are used as effective rootstocks for its tolerance capacity to phylloxera and nematodes infection in grapes (Nicholas et al., 1997). Brooks and Olmo, (1997) [16] founded that cultivars Harmony and Freedom are the first root-knot nematode resistant rootstocks derived from complex crosses among $V$. champinii, $V$. longii, $V$. vinífera, $V$. riparia and $V$. labrusca. Ferris et al., (2013) ${ }^{[36]}$ reported that $V$. champinii cultivars Ramsey and Dog Ridge emerged as exhibiting durable resistance to root-knot nematodes. The rootstocks UCD GRN1 and VR O39-16 used for resistance to the root lesion nematode.

Table 1: List of resistant/ tolerant rootstocks in fruit crops.

\begin{tabular}{|c|c|c|c|}
\hline Crop & Rootstocks & Resistance/tolerance traits & References \\
\hline & $13-1$ & Tolerant to salinity & Gunjate, $2009^{[45]}$. \\
\hline & Carabao, Pico Manga d Agua & Resistant to wilt & Ribeiro et al., $1993^{[84]}$. \\
\hline & IAC 103 Macoca \& IAC 108 Pindorama & Resistant to C. fimbriata & Rossette et al., $1996^{[85]}$. \\
\hline & Gomera-1 & Tolerant to salinity & Duran et al., $2003^{[32]}$. \\
\hline & $13 / 3$ & Tolerant to salinity & Gunjate, $20099^{[45]}$. \\
\hline & Kurukan & Tolerant to salinity & Dubey et al., $2007^{[31]}$. \\
\hline & Olour and Bappakkai & Tolerant to salinity & 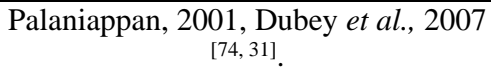 \\
\hline \multirow{3}{*}{ Guava } & $\begin{array}{l}\text { Psidium friedrichsthalianum P. cattleianum var. } \\
\text { lucidum }\end{array}$ & $\begin{array}{l}\text { Resistance to root-knot } \\
\text { nematode }\end{array}$ & Freitas et al. (2014) ${ }^{[39]}$, \\
\hline & Psidium guineense & $\begin{array}{l}\text { Resistance to root-knot } \\
\text { nematode }\end{array}$ & Costa et al., $2012^{[23] .}$ \\
\hline & Crioula & Tolerant to salinity & Souza et al., $2016^{[92]}$. \\
\hline \multirow{13}{*}{ Grapes } & Dimple, Jonelle, GU 8 & $\begin{array}{l}\text { GWD resistance } \\
\text { Nematode tolerance } \\
\text { Salinity tolerance }\end{array}$ & Vos, $2000^{[100]}$ \\
\hline & GU8 P. longipes and P. arayan & $\begin{array}{l}\text { Root Knot Nematode resistant } \\
\text { Root stock }\end{array}$ & Milan, (2007) \\
\hline & Ramsey and Dog Ridge & $\begin{array}{l}\text { Resistance to root-knot } \\
\text { nematodes }\end{array}$ & Ferris et al., $2013^{[36] .}$ \\
\hline & UCD GRN1 and VR O39-16 & $\begin{array}{l}\text { Resistance to the root lesion } \\
\text { nematode }\end{array}$ & Ferris et al., $2013^{[36]}$. \\
\hline & Ramsey,Riparia Glorie, 5C & screened for salt tolerant & Kevin Fort and Andrew Walker, 2008 \\
\hline & Harmony andFreedom & $\begin{array}{c}\text { Resistance to root-knot } \\
\text { nematodes }\end{array}$ & Brooks and Olmo $1997{ }^{[16] .}$ \\
\hline & $\begin{array}{l}\text { Ramsey and } \\
1103 \text { Paulsen }\end{array}$ & $\begin{array}{c}\text { Tolerance of phylloxera and } \\
\text { nematodes }\end{array}$ & Nicholas et al., 1997 \\
\hline & $140 \mathrm{Ru}$ & $\begin{array}{c}\text { Tolerance to water deficit } \\
\text { condition }\end{array}$ & Tarmontini et al., $2013^{[95]}$. \\
\hline & Beta & Cold hardiness & Lu jinxing et al., $2012^{[64]}$. \\
\hline & $3309 \mathrm{C}$ & Cold hardiness & Striegler et al., $1991^{[94]}$. \\
\hline & A15 and A17 & Tolerance to alkalinity & Guo Shu-Hua et al., $2018^{[46]}$. \\
\hline & Hybrids of $V$. berlandieri $x V$. riparia & Tolerance to drought & Kocsis et al., $1999^{[59]}$ \\
\hline & 196-17, CH-1, CH-2 & Tolerance to salinity & Troncoso et al., $1999^{[96]}$. \\
\hline \multirow{2}{*}{ Avocado } & G755C13-1 & Salinity tolerance & Kadman, $1984^{[54]}$. \\
\hline & Duke 7 and G6 & Resistance to P. cinnamomi & Kellam et al., $1985^{[57]}$. \\
\hline Loquat & Anger & Tolerance to Saline conditions & Garcia-Legaz et al., 2003 \\
\hline \multirow{6}{*}{ Citrus } & C. Macrophylla & Resistance to salinity & Garcia legaz et al., 1993 \\
\hline & $\begin{array}{c}\text { Mandarin- Clemenules trees grafted on Carizo } \\
\text { performed well }\end{array}$ & Resistance to salinity & Garcia-Legaz et al., $2006^{[40]}$. \\
\hline & Pearl, Mosambi x kinnow \& mosambi x Nagpur & Resistant against citrus pyslla & Sharma et al., $2005^{[89]}$. \\
\hline & Star ruby and ruby red & Resistant against citrus pyslla & Sharma et al., $2005^{[89]}$. \\
\hline & $\begin{array}{c}\text { F \& A 418, \#23, \#24 Hybridization (Troyer citrange X } \\
\text { Cleopatra mandarin) }\end{array}$ & Dwarfing rootstock & Ignacio-lliso et al., $2004{ }^{[52]}$. \\
\hline & US 852 Hybrid Selection & Phytophthora resistance & Bowman et al., $1999^{[14,15]}$ \\
\hline
\end{tabular}

Sapota (Achras zapota L.)

Sapota popularly known as 'Sapodilla' or 'Chicku', can flourish well on a wide range of soils like alluvial, sandy loam, red laterite and medium black type with temperature ranging from $11{ }^{0} \mathrm{C}$ to $34{ }^{\circ} \mathrm{C}$. Commercial cultivation of sapota for better yield and fruit quality through grafted saplings. Species like Achras zapota, Mimusops hexandra, Mimusops kauki, Madhuca latifolia, Bassia longifolia and Chrysophyllum cainito have been reported as rootstocks for sapota (Bose, 1985). Kalesh et al., (2005) ${ }^{[13]}$. found that a new indigenous rootstock for sapota $C$. lanceolatum and it is wild species is rather sustainably disease resistant, profuse flowering, seed fertility over $95 \%$ and wide adaptability with different kinds of soils. Mohammadi et al., (2018) [68, 69] reported that morphological and antioxidant enzymatic activity responses of sapodilla rootstock to salinity stress resulting in Manilkara hexandra showing very slow growth rate and there are no morphological changes during the stress 
period. During the saline condition, the antioxidant enzymes increased strongly and peroxidase (POD) and catalase (CAT) activities were also increased.

\section{Avocado (Persea americana)}

Avocado is a new commercial fruit crop which is very sensitive to salinity and climatic factors prevailing in the subtropics, especially drought and extreme temperatures. Extreme temperatures result in low productivity and sometimes even in severe damage to the tree canopy. In Avocado, particularly Mexican race are extremely sensitive to salinity and found that trees grafted on West Indian rootstocks could survive the relatively saline condition but trees grafted on Mexican rootstocks suffered and finally died. And it is the first discovery of the West Indian avocado used as rootstock for resistance to salinity.

Under such condition, chloride toxicity is high include reductions in fruit yield and tree size, lowered leaf chlorophyll content, decreased photosynthesis, poor root growth and leaf scorching. West Indian race was found to be more resistant to salinity than Mexican race. Under saline condition, Mexiacn race induced greater accumulation of $\mathrm{Cl}$ in the leaves whereas West Indian race the $\mathrm{Cl}$ accumulation is very less. Phytophthora root rot is a major problem in avocado cultivation and it predominately occurs in saline soils. There are two Mexican avocado selections like Duke 7 and G 6 showed more tolerance to avocado root rot due to moderate horizontal resistance to P.cinnamomi. Whereas, susceptible rootstocks Walter Hole and Topa Topa to P.cinnamomi. Topa-Topa rootstock accumulated more $\mathrm{Cl}$ and Duke less $\mathrm{Cl}$ than other rootstocks. Under greenhouse, shoot biomass production was approximately one-half that observed for Duke 7 at all chloride concentrations and showed tolerance to root rot (David Crowley et al., 1999) ${ }^{[25]}$.

\section{Loquat (Eriobotrya japonica Lindl.)}

Loquat is commercially grown in subtropical to mild temperate climate (Lin et al., 2007). Commonly loquat plants are grafted onto anger (Cydonia oblonga Mill.) rootstock which is smaller hence have a lower cost of production (Burlo-Carbonell et al., 1997). Under the saline condition, photosynthesis and dry matter production strongly affected and reduces the growth of the tree. However, the relationship between photosynthesis and salinity is influenced both by the rootstock and the scion. Loquat grafted onto anger had lower $\mathrm{Na}$ concentrations in their leaves than those grafted onto loquat and lower concentrations of $\mathrm{Cl}$ at the highest salinity. Anger rootstocks permitted some plant growth under saline conditions due to their ability to reduce the transport of $\mathrm{Na}$ and $\mathrm{Cl}$ to the shoots and leaves from roots (Garcia-Legaz et al., 2008) ${ }^{[42]}$. According to Lopez gomezb et al., (2007) ${ }^{[62]}$ loquat grafted on anger rootstock did not the affected growth of loquat plants under moderate $(20 \mathrm{mM})$ and high $(35 \mathrm{mM})$ concentration of $\mathrm{NaCl}$ in the nutritive solution. But loquat grafted on loquat rootstock under $20 \mathrm{mM} \mathrm{NaCl}$ condition which leads to a $44 \%$ decrease in plant growth, whereas the higher $\mathrm{NaCl}$ concentration used produced a $65 \%$ of plant growth inhibition. Garcia-Legaz et al., (2008) ${ }^{[42]}$ reported that salinity tolerance differences between the logan and anger were not due to ion uptake and translocation from roots to leaves or to the osmotic effect induced by salinity. Under the saline condition, anger rootstock showed higher tolerance to salinity due to higher capacity to compartmentalize toxic ions in vacuoles or to scavenge activated oxygen species.

\section{Citrus (Citrus spp)}

Citrus is one of the important major commercial fruit crops and occupies a prominent position in the fruit industry. Citrus growers are facing many problems viz., salinity, drought, different microorganisms (fungi, bacteria and viruses etc.), pests and nematodes affecting the quality and quantity of citrus. Choosing the right rootstocks is fundamental to the success of the citrus industry worldwide (Wheaton et al., $1995)^{[103]}$. In citriculture, the rootstocks are played a major role for the success of citrus cultivation for its resistance to various biotic and abiotic stresses and it has strongly influenced the tree canopy, vigour and yield Forner-Giner et al., (2020) ${ }^{[38]}$. Traditional sensing technologies in fruit crops field surveys and phenotyping are requiring more time and labour intensive. Nowadays UAV-based remote sensing and artificial intelligence are used for citrus rootstock evaluation by monitoring the phenotypic changes of plants (Ampatzidis et al., 2019; Ampatzidis and Partel, 2019; Csillik et al., 2018) $[6,7,26]$. In 1842 the first rootstock was used in citriculture to control root rot caused by Phytophthora in Azores Islands through the use of resistant rootstocks. Citrus salt tolerance is associated with both the rootstock's ability to restrict the accumulation of chloride and/or sodium. C. macrophylla showed higher resistance to salinity than $C$. volkameriana and used as rootstock for tolerance to salinity in lemon. When the lemon budded on $C$. volkameriana, the increase in leaf sodium concentration would be the most influential factor affecting gas exchange rates. Whereas in lemon budded on $C$. macrophylla or sour orange leaf chloride concentration would be the main factor affecting the gas exchange rates. Cleopatra roots accumulated higher concentrations of $\mathrm{Cl}^{-1}$ and $\mathrm{Na}$ than Carrizo roots but 'Sunburst' leaves on Cleopatra accumulated less $\mathrm{Cl}^{-1}$ and $\mathrm{Na}$ and had higher $\mathrm{CO}_{2}$ exchange rates than those on Carrizo (Garcia-Sanchez et al., 2002). Raga et al., (2014) [43, 79] reported that salinity decreased yield and juice volume but improved the total soluble solids and rind thickness. The highest $\mathrm{CO}_{2}$ assimilation was connected with best $\mathrm{Na}^{+}$ exclusion from the leaves. In other studies, $\mathrm{Na}^{+}$and $\mathrm{Cl}^{-}$ contents in citrus leaves were mainly depended on scion and to a lesser degree depended on rootstock. Rao et al., $(2001)^{[80]}$ reported that Gal Gal, Kagzi lime and Karna khatta showed no psylla population were tolerant and used as rootstock for tolerance to Citrus psylla in Meghalaya areas. Under deficitirrigation in semi-arid regions, Cleopatra mandarin can mitigate more the negative effects of drought stress and maintain better plant water status and higher gas-exchange activity than Carrizo citrange (Perez et al., 2008) ${ }^{[78]}$. Rootstocks like Pearl, mosambi $\mathrm{x}$ kinnow and mosambi $\mathrm{x}$ Nagpur showed resistance to whitefly while citranges such as Carrizo and troyer were highly susceptible. Kinnow and local mandarin showed resistant against citrus pyslla and papeda and lemon were moderately resistant (Sharma et al., 2005) ${ }^{[89]}$. Javed et al., (2008) [53] found that citrus root stocks for resistance to citrus nematode (Tylenchulus semipenetrans Cobb.), Carrizo citrang, Citromela and Grapefruit were resistant. Savageage citrange and Sachton citrumelo were shown moderate resistant to citrus root nematode whereas some cultivars moderately suceptable like Gadi Dahi, Yuma citrange and Kharana khata. Sharma et al., (2005) ${ }^{[89]}$ reported that grapefruit cv. Star Ruby and Ruby Red exhibited resistance to whitefly infection. Byrne et al., (1995) ${ }^{[18]}$ found that Volkameriana and sour orange were tolerant Carrizo and Troyer citranges were intermediate, whereas the Poncirus trifoliata rootstock was more sensitive to iron chlorosis. Similar results were reported by Alvarez-Fernández et al., (2006) and Castle et al., (2009) ${ }^{[5,20]}$. 
Table 2: Characteristics of some resistance/tolerance citrus rootstocks (Chadha and Singh, 1990).

\begin{tabular}{|c|c|c|c|c|c|c|}
\hline \multirow{2}{*}{ Rootstock } & \multicolumn{5}{|c|}{ Reaction to } \\
\cline { 2 - 6 } & Root rot & Nematode & Tristeza & Exocortis & Salt & Drought \\
\hline Rangpur lime & MT & S & R & S & R & R \\
\hline Marmalade Orange & MT & MT & R & S & R & R \\
\hline Rough lemon & S & S & R & R & T & T \\
\hline Cleopatra mandarin & T & S & R & R & MT & S \\
\hline Sour lime & R & T & HS & T & T & MT \\
\hline Sweet lime & S & MT & S & S & S & S \\
\hline Trifoliate orange & R & R & R & H & HS & HS \\
\hline Troyer citrange & MT & T & MT & S & HS & HS \\
\hline Carrizo orange & MT & T & MT & S & HS & HS \\
\hline Sweet orange & HS & HS & MT & R & S & S \\
\hline Karna khatta & S & MT & - & T & T & S \\
\hline Nasanaran & S & MT & T & R & HT & S \\
\hline
\end{tabular}

$\mathrm{M}=$ Moderate, $\mathrm{R}=$ Resistant, $\mathrm{T}=$ Tolerant, $\mathrm{MT}=$ Moderately tolerant, $\mathrm{S}=$ Susceptible, $\mathrm{HS}=$ Highly susceptible,

\section{Pomegranate (Punica granatum L.)}

Pomegranate is a very interesting fruit for its adaptation to a wide range of climates and soil conditions. The climatic change affects proline accumulation in pomegranate fruits and hot and dry years, proline accumulation in fruits increases. (Hanim and Nesrin, 2009). Under deficient irrigation, pomegranate plants more tolerant to drought and use less water. Kaimi and Hassanpour, (2017) ${ }^{[56]}$ reported that Tab-oLarz rootstock restricts the uptake or transport of sodium and chloride from root to shoot. According to Hasanpour et al., (2015) ${ }^{[47]}$ selection of drought tolerant seedling by growing plants under water stress condition and resulted that Wonderful variety accumulated high values of proline content under water stress condition then Early 166 variety. Hence, the pomegranate variety Wonderful showed tolerant to drought condition when compared to Early 116 variety. ValizadehKaji et al., (2020) ${ }^{[99]}$ found that Daneshgah 13, Daneshgah 32 and Daneshgah 8 used as rootstocks showed maximum drought tolerance among the cultivars.

\section{Fig (Ficus carica)}

Plants under the saline condition which ultimately affect crop yield and quality depend on the crop species and cultivars, salinity level, the composition of salt, exposed period to salinity, the growth stage of plants, and several environmental factors Del Amor et al., (1999); Carvajal et al., (1998) ${ }^{[29,19]}$. Masui Dauphine fig grafted on zidi, biter abiod, king and own rooted were grown in 6 different areas and among four rootstocks zidi performs well even in soil sickness condition and it is a suitable rootstock for tolerance to soil sickness (Hosomi et al., 2002). Grattan and Grieve, (1999) ${ }^{[50,44]}$ stated that high concentrations of $\mathrm{Na}+$ and $\mathrm{Cl}-$ in the root depress nutrient ion activities and produce extreme rations of $\mathrm{Na}^{+} / \mathrm{Ca}^{2+}, \mathrm{Na}^{+} / \mathrm{K}^{+}, \mathrm{Ca}^{2+} / \mathrm{Mg}^{2+}$, and $\mathrm{Cl}^{-} / \mathrm{NO}^{3}-$. Hence, the plants become nutritional deficiency, specific ion injury that may result in reduced yield and quality.

\section{Papaya (Carica papaya)}

Papaya is also known as wonder fruit of tropics which is grown in almost every part of the country. According to Noraisah Sarip et al., (2018) ${ }^{[72]}$ Viorica a promising rootstock in producing high tolerance against Papaya Dieback Disease by grafting method and more than $90 \%$ success rate was obtained and used in reducing the susceptibility of elite scions. Pecanha et al., (2010) [76] reported that papaya rootstock Tainung1 perform better to provide water to the shoot and a good vascular connection between the scion and rootstock thereby maintaining high gas exchange and photochemical efficiency in the leaves and consequently a greater carbon gain. Chlorophyll fluorescence was the highest (0.83) in Tainung 1 seedlings and the lowest (0.73) in Golden/Tainung 1 combination.

\section{Conclusions}

Both abiotic and biotic stress especially drought, salinity, temperature stress, fungal and other diseases of microbes in fruit crops have led to a reduction in yield and or crop failure. Hence, the use of different types of stress specific rootstocks in fruit crops would play a major role in increasing the productivity of fruit crops under various stressful conditions. Many challenges of the rootstock breeding programmer have been addressed effectively to some extend by combining the traditional rootstock breeding with modern breeding methods such as molecular breeding to save time and space. Although the source of rootstock, resistance to biotic and abiotic stresses has been reported by several workers, the research progress is very slow and needs to be hastened. Still, more efforts are needed to evaluate rootstocks with resistance to various traits and its use as rootstock directly or by introgression into commercial cultivars, compatibility of the tolerant/ resistant rootstock with various commercial cultivars. The trend in rootstock breeding is to incorporate more traits into the roster of ideotype features. Production trends are towards reduced chemical inputs, a fewer pass by hand labour crews, and higher production with more plants per unit area, more goals for breeding programmes will increase the intractability of rootstock improvement. It is visualizes and selecting suitable rootstock so that, the potential possibility of the scion variety could gain for sustainable production.

\section{Conflict of interest}

We hereby submit that there is no conflict of interest over this manuscript either among the authors or the sponsors.

\section{References}

1. Acosta-Rangel AM, Li R, Celis N, Suarez DL, Santiago LS, Arpaia ML et al. The physiological response of 'Hass' avocado to salinity as influenced by rootstock. Scientia Horticulturae. 2019; 256:108629.

2. Ahmad R, Anjum MA. Physiological and molecular basis of salinity tolerance in fruit crops. In Fruit Crops, 2020; 445-464. Elsevier.

3. Ahmed N, Khalid S, Grewal AG, Ali MA, Anjum MA, Rahi AA et al. performance of mango scion cultivars under various levels of artificially induced salinity stress. Pak. J. Bot. 2020; 52:4. 
4. Ali-Dinar HM, Ebert G, Ludders P. Growth, chlorophyll content, photo synthesis and water relations in guava (Psidium guajava L) under salinity and different nitrogen supply. Gartenbauwissenschaft. 1999; 64(2):84

5. Alvarez-Fernández A, Abadía J, Abadía A. Iron deficiency, fruit yield and fruit quality. In: Barton LL, Abadía J, editors. Iron Nutrition in Plants and Rizospheric Microorganisms. Dordrecht: Springer. 2006; 437-448. DOI: 10.1007/1-4020-4743-6_4.

6. Ampatzidis Y, Partel V. UAV-based high throughput phenotyping in citrus utilizing multispectral imaging and artificial intelligence. Remote Sensing. 2019; 11(4):410.

7. Ampatzidis Y, Partel V, Meyering B, Albrecht U. Citrus rootstock evaluation utilizing UAV-based remote sensing and artificial intelligence. Computers and Electronics in Agriculture. 2019; 164:104900.

8. Anonymous. Annual Report, Central Institute for Subtropical Horticulture, Lucknow, 2016-17; pp. 15.-

9. Bagheri A, Hassanzadeh KH, Ghanbari V, Askari SM, Modarres NSS. Genetic Diversity among Mango (Mangifera indica L.) Genotypes in Hormozgan Province Using Morphological and ISSR Markers, 2019.

10. Balan P. Kesar farmers to reap fruits of Israel technology, 2017.

http://timesofindia.indiatimes.com/city/ahmedabad/kesarfarmers-to-reap-fruits-ofisraeltech/articleshow/59451835.cms

11. Bastianel M, Schwarz SF, Coleta Filho HD, Lin LL, Machado M, Koller OC et al. Identification of zygotic and nucellar tangerine seedlings (Citrus spp.) using RAPD. Genetics and Molecular Biology, 1998; 21(1).

12. Bezerra IL, gheyi HR, Nobre RG, Barbosa JL, Fatima RTD, Elias JJ et al. Physiological alterations and production of guava under water salinity and nitrogen fertilizer application. Ciências Agrárias, Londrina, 2018; 39(5):1945-1956.

13. Bose TK. Fruits of India- Tropical and subtropical. Naya Prokash, Calcutta, India, 1985.

14. Bowman KD. A new hybrid citrus rootstock for Florida: US-852. In Proceedings of the Florida State Horticultural Society. 1999; 112:54-55

15. Bowman KD, Wutsher HK, Kalplan DT, Chaparro JXA. new hybrid citrus rootstock for Florida: US - 852. Proc. Fla State Hort. Soc. 1999; 112:54-55.

16. Brooks RM, Olmo HP, Brooks RM. Brooks and Olmo register of fruit \& nut varieties. ASHS press, 1997.

17. Burló-Carbonell F, Carbonell-Barrachina A, Vidalroig A, Mataix-Beneyto J. Effects of irrigation water quality on loquat plant nutrition: sensitivity of loquat plant to salinity. Journal of Plant Nutrition. 1997; 20:119-30.

18. Byrne DH, Rouse RE, Sudahono S. Tolerance to citrus rootstocks to lime-induced iron chlorosis. Subtropical Plant Sci. 1995; 47:7-11

19. Carvajal M, Del Amor FM, Fernandez-Ballester G, Martinez V, Cerda A. Time course of solute accumulation and water relations in muskmelon plants exposed to salt during different growth stages. Plant Sci. 1998; 38:103-112. DOI: 10.1016/ S0168-9452(98)00158.

20. Castle WS, Nunnallee J, Manthey JA. Screening Citrus rootstocks and related selections in soil and solution culture for tolerance to low-iron stress. HortScience. 2009; 44:638-645

21. Chadha K L, Singh H P. Citriculture scenario of India. in Citriculture in North- western India: Proceedings of Citrus Show-cum-Seminar. Prospects and Problems of
Kinnow Cultivation (K.S. Gill, J.S. Kanwar and R. Singh, eds.). Punjab Agricultural University, Ludhiana, 1990, 21-64.

22. Chell I-Chaabounia A, Mosbahb AB, Maalej M, Gargouric K, Gargouri-Bouzidd R, Drira $\mathrm{N}$ et al. In vitro salinity tolerance of two pistachio rootstocks: Pistacia vera L. and $P$. atlantica Desf. Env. Exp. Bot. 2010; 69:302-312

23. Costa SR, Santos CAF, Castro JMC. Assessing Psidium guajava, $P$. guineense hybrid tolerance to Meloidogyne enterologii. Acta Horticulture. 2012; 959:59-66

24. Cronk QCB, Fuller JL. Plant Invaders. People and Plants Conservation Manual, 1995.

25. Crowley D, Smith W, Arpaia ML. Rootstock selections for improved salinity tolerance of avocado. Proceeding of Avocado Brainstorming, Eds. Arpaia, M.L. and R. Hofshi, October. 1999; (27-28):78-80.

26. Csillik O, Cherbini J, Johnson R, Lyons A, Kelly M. Identification of citrus trees from unmanned aerial vehicle imagery using convolutional neural networks. Drones. 2018; 2(4):39.

27. Cuneo IF, Barrios-Masias F, Knipfer T, Uretsky J, Reyes $\mathrm{C}$, Lenain P, McElrone AJ et al. Differences in grapevine rootstock sensitivity and recovery from drought are linked to fine root cortical lacunae and root tip function. New Phytologist, 2020.

28. Dalbo MA. Genetic mapping, QTL analysis and markerassisted selection for disease resistance loci in grapes, 1999.

29. Del Amor FM, Martinez V, Cerda A. Salinity duration and concentration affect fruit yield and quality and growth and mineral composition of melon plants grown in perlite. Hort. Science. 1999; 34:1234-1237

30. Dikilitas M, Simsek E, Roychoudhury A. Role of Proline and Glycine Betaine in Overcoming Abiotic Stresses. Protective Chemical Agents in the Amelioration of Plant Abiotic Stress: Biochemical and Molecular Perspectives, 2020, 1.

31. Dubey AK, Srivastav M, Sharma YK, Pandey RN, Deshmukh PS. Dry mass production and distribution of nutrients in two mango rootstocks as affected by salinity. Indian Journal of Horticulture. 2007; 64(4):670-72.

32. Duran VH, Raya AM, Aguilar J. Salt tolerance of mango rootstocks (Magnifera indica L. cv. Osteen). Spanish Journal of Agricultural Research. 2003; 1(1):68-78.

33. Ebert G, Eberle J, Ali-Dinar H, Lüdders P. Ameliorating effects of $\mathrm{Ca}$ (NO3) 2 on growth, mineral uptake and photosynthesis of $\mathrm{NaCl}$-stressed guava seedlings (Psidium guajava L.). Scientia Horticulturae. 2002; 93(2):125-135

34. El-Banna, MF, Loay AA. Evaluation berries shattering phenomena of 'Flame seedless' vines grafted on different rootstocks during shelf life. Scientia horticulturae. 2019; 246:51-56.

35. Elsheery NI, Helaly MN, El-Hoseiny HM, Alam-Eldein SM. Zinc Oxide. Silicone Nanoparticles to Improve the Resistance Mechanism and Annual Productivity of SaltStressed Mango Trees. Agronomy. 2020; 10(4):558.

36. Ferris H, Zheng L, Walker MA. Soil temperature effects on the interaction of grape rootstocks and plant-parasitic nematodes. Journal of nematology. 2013; 45(1):49.

37. Flowers TJ. Improving crop salt tolerance. Journal of Experimental botany. 2004; 55(396):307-319. 
38. Forner-Giner MA, Continella A, Grosser JW. Citrus Rootstock Breeding and Selection. In The Citrus Genome, 2020, 49-74. Springer, Cham.

39. Freitas VM, Correa VR, Motta FC, Sousa MG, Gomes ACMM, Carneiro MDG et al. Resistant accessions of wild Psidium spp to Meloidogyne enterolobii and histological characterization of resistance. Plant Pathology. 2014; 63(4):738-746.

40. Garcia Sanchez F, Perez-perez JG, Botia P, Martinez V. The response of young mandarin trees grown under saline condition depends on the rootstock. Europ. $\mathrm{j}$ Agronomy. 2006; 24:129-139

41. García-Legaz F, Lápez Gomez E, Mataix-Beneyto J, Sánchez-Blanco MJ, Ferrández T, Torrecillas A et al. Influence of water salinity on growth and water relations of loquat plants grafted on two rootstocks. In IV International Symposium on Irrigation of Horticultural Crops. 2003; 664:261-267.

42. García-Legaz MF, Lopez-Gomez E, Beneyto JM, Navarro A, Sánchez-Blanco MJ. Physiological behaviour of loquat and anger rootstocks in relation to salinity and calcium addition. Journal of plant physiology. 2008; 165(10):1049-1060.

43. García-Sánchez F, Jifon JL, Carvajal M, Syvertsen JP. Gas exchange, chlorophyll and nutrient contents in relation to $\mathrm{Na}+$ and $\mathrm{Cl}-$ accumulation in 'Sunburst' mandarin grafted on different rootstocks. Plant Science. 2002; 162(5):705-712

44. Grattan ST, Grieve CM. Salinity mineral relations in horticultural crops. Sci. Hortic. 1999; 78(1-4):127-157, DOI: 10.1016/S0304-4238(98)00192-7.

45. Gunjate RT. Advances in mango culture in India. Acta Hort. 820:69-78 Litz, R.E. 2009. Mango. Wiley Publishers, 2009, 530.

46. Guo SH, Niu YJ, Zhai H, Han N, Du YP. Effects of alkaline stress on organic acid metabolism in roots of grape hybrid rootstocks. Scientia Horticulturae. 2018; 227:255-260

47. Hasanpour Z, Karimi HR, Mirdehghan SH. Effects of salinity and water stress on echophysiological parameters and micronutrients concentration of pomegranate (Punica granatum L.). Journal of plant nutrition. 2015; 38(5):795807.

48. Hochberg U, Degu A, Toubiana D, Gendler T, Nikoloski $\mathrm{Z}$, Rachmilevitch $\mathrm{S}$ et al. Metabolite profiling and network analysis reveal coordinated changes in grapevine water stress response. BMC plant biology. 2013; 13(1): 184 .

49. Hodda M, Banks NC, Singh SK. Nematode threats in the NAQS region.In. Book. CSIRO. 2012, 1-82.

50. Hosomi A, Dan M, Kato A. Screening of fig varieties for rootstocks resistant to soil sickness. Journal of the Japanese Society for Horticultural Science. 2002; 71(2):171-176

51. Ibacache A, Verdugo-Vásquez N, Zurita-Silva A. Rootstock: Scion combinations and nutrient uptake in grapevines. In Fruit Crops, 2020, 297-316. Elsevier.

52. Ignacio Lliso, Juan B Forner, Manuel Talon. The dwarfing mechanism of citrus rootstocks F \& A 418 and \#23 is related to competition between vegetative and reproductive growth. Tree Physiology. 2004; 24:225-232.

53. Javed N, Javed M, Ilyas MB, Khan MM, Inam-Ul-Haq M. Reaction of various citrus root stocks (germplasm) against citrus root nematode (Tylenchulus semipenetrans Cobb.). Pak. J Bot. 2008; 40(6):2693-2696.
54. Kadman A. Selection of avocado and mango rootstocks for calcareous soils. In $\mathrm{X}$ African Symposium on Horticultural Crops 158, 1984, 63-68.

55. Kalesh K, Shareef SM, Mathew SP, Chemburkar MS. Chrysophyllum lanceolatum-a new rootstock for sapota (Achras zapota L.). Journal of Applied Horticulture. 2005; 7(1):23-24.

56. Karimi HR, Hassanpour N. Effects of salinity, rootstock, and position of sampling on macro nutrient concentration of pomegranate cv. Gabri. Journal of Plant Nutrition. 2017; 40(16):2269-2278.

57. Kellam MK, Coffey MD. Quantitative comparison of the resistance to Phytophthora root rot in three avocado rootstocks. Phytopathology. 1985; 75(2):230-234.

58. Kevin Forte, Andrew Walker M. Breeding salinity tolerant grape rootstocks, Proceedings of the $2^{\text {nd }}$ Annual National Viticulture Research Conference, 2008.

59. Kocsis L, Granett J, Walker MA, Lin H, Omer AD. Grape phylloxera populations adapted to Vitis berlandieri $x$ V. riparia rootstocks. Am. J Enol. Vitic. 1999; 50:101106.

60. Li M, Guo Z, Jia N, Yuan J, Han B, Yin Y et al. Evaluation of eight rootstocks on the growth and berry quality of 'Marselan'grapevines. Scientia horticulturae. 2019; 248:58-61.

61. Lin S, Huang X, Cuevas J, Janick J. Loquat: An ancient fruit crop with a promising future. Chronica Hort. 2007; 47:12-15.

62. López-Gómez E, San Juan MA, Diaz-Vivancos P, Beneyto JM, García-Legaz, MF, Hernández JA et al. Effect of rootstocks grafting and boron on the antioxidant systems and salinity tolerance of loquat plants (Eriobotrya japonica Lindl.). Environmental and experimental botany. 2007; 60(2):151-158.

63. Lozano-Gutiérrez J, España-Luna MP, Velásquez-Valle R, Gallegos-Morales G, Cepeda-Siller M, GonzálezGaona E et al. Evaluation of Mexican guava germplasm against root knot nematodes. In II International Symposium on Guava and other Myrtaceae. 2008; 849:363-368.

64. Lu J, Jiang H, Li W. Effects of low temperature stress on the cold resistance of rootstock and branch of wine grapes. Journal of Fruit Science. 2012; 29(6):1040-1046.

65. Luvaha E, Netondo GW, Ouma G. Responses of mango (Mangifera indica L.) root stock seedlings to water stress. International Journal of Botany. 2007; 3(4):373-378.

66. Mehanna HT, Fayed TA, Rashedy AA. Response of two grapevine rootstocks to some salt tolerance treatments under saline water conditions. Journal of Horticultural Science \& Ornamental Plants. 2010; 2(2):93-106.

67. Mestre PF, Asins MJ, Pina JA, Carbonell EA, Navarro L. Molecular markers flanking citrus tristeza virus resistance gene from Poncirus trifoliata (L.) Raf. Theoretical and Applied Genetics. 1997; 94(3-4):458464.

68. Mohammadi Z, Rastegar S, Abdollahi F, Hosseini Y. Morphological and antioxidant enzymatic activity responses of sapodilla rootstock to salinity stress. J Plant Process Funct. 2018; 6:23-28.

69. Mohammadi Z, Rastegar S, Abdollahi, Hosseini Y. Morphological and antioxidant enzymatic activity responses of sapodilla rootstock to salinity stress. J Plant Process Funct. 2018; 6:23-28.

70. Negi SS, Rajan S. Improvement of guava through breeding. Acta Horticulture. 2007; 735:31-37. 
71. Nimbolkar PK, Shiva B, Rai AK. Rootstock breeding for abiotic stress tolerance in fruit crops. International Journal of Agriculture, Environment and Biotechnology. 2016; 9(3):375-380.

72. Noraisah R, Puteri DEZ, Fauzam CH, Zulfa MR. Viorica: A Promising Rootstock in Producing Highly Tolerance Grafted Papaya against Papaya Dieback Disease. Plant Productivity and Environmental Conservation, 2018, 56.

73. Normand F. Strawberry guava, relevance for Reunion. Fruits. 1994; 49:217-27.

74. Palaniappan. Germplasm screening for salinity stress in tropical fruit species. Regional Training Course "Characterization, Evaluation and Conservation of Tropical Fruits Genetic Resources”, organized by IPGRI, ICAR and IIHR, 2001.

75. Pavlousek P. Evaluation of drought tolerance of new grapevine rootstock hybrids. Journal of Environmental Biology. 2011; 32(5):543.

76. Peçanha L, Campostrini E, Torres Netto A, YamanishI O $\mathrm{K}$, Lima LA, Naves RV et al. Gas-exchange and photochemical efficiency in seedling and grafted papaya tree grown under field condition. Acta Hortic. 2010; 851:271-278.

77. Pérez-Jiménez M, Pérez-Tornero O. Improved salttolerance in Citrus macrophylla mutant rootstocks. Scientia Horticulturae. 2020; 259:108815.

78. Perez-Pere JG, Romero P, Navarro JM, Botía P. Response of sweet orange cv 'Lane late' to deficitirrigation strategy in two rootstocks. II: Flowering, fruit growth, yield and fruit quality. Irrigation Science. 2008; 26(6):519.

79. Raga V, Bernet GP, Carbonell EA, Asins MJ. Inheritance of rootstock effects and their association with salt tolerance candidate genes in a progeny derived from 'Volkamer'lemon. Journal of the American Society for Horticultural Science. 2014; 139(5):518-528.

80. Rao KR, Shylesha AN, Pathak AK. Spatial dynamics of citrus mealybug Planococcus citri Risso at medium high altitudes of Meghalaya. Indian J Hill Farm. 2001; 14(2):48-52.

81. Rebolledo-Martínez A, Peralta-Antonio N, RebolledoMartínez L, Becerril-Román EA, Rebolledo-García RL. Effect of rootstock in tree growth, dry matter, flowering, yield and quality of 'Manila'mango. Scientia Horticulturae. 2019; 251:155-161.

82. Reddy YTN, Kurian RM, Ramachander PR, Singh G, Kohli RR. Long-term effects of rootstocks on growth and fruit yielding patterns of 'Alphonso'mango (Mangifera indica L.). Scientia Horticulturae. 2003; 97(2):95-108.

83. Redondo-Gómez. Susana Abiotic and biotic stress tolerance in plants. In: Molecular Stress Physiology of Plants. Springer, 2013, 1-20.

84. Ribeiro IJA, Rossetto CJ, Donadio LC, Sabino JC, Martins AIM, Gallo PB et al. Mango Wilt. XIV Selection of mango (Mangifera indica L.) rootstocks resistant to the mango wilt Fungus Ceratocystis fimbriata Ell \& Halst. In International Symposium on Tropical Fruits, 370, 1993, 159-166.

85. Rossetto CJ, Ribeiro IJA, Gallo PB, Soares NB, Sabino JC, Martins ALM et al. Mango breeding for resistance to diseases and pests. In V International Mango Symposium. 1996; 455:299-304.

86. Sathisha J, Ramteke SD, Karibasappa GS. Physiological and biochemical characterization of guava rootstocks. S. Afr. J Enol. Vitic. 2007; 28(2):163-168
87. Schmid J, Manty F, Rühl EH. Experience with phylloxera tolerant and resistant rootstocks at different vineyard sites. In Workshop on Rootstocks Performance in Phylloxera Infested Vineyards. 2001; 617:85-93.

88. Serra A, Strever P, Myburgh A. Deloire A Review: the interaction between rootstocks and cultivars (Vitis vinifera L:) to enhance drought tolerance in grapevine. Aust. J. Grape Wine Res. 2014; 20:1-14

89. Sharma DR, Kumar R, Rattanpal HS. Reaction of citrus germplasm against Citrus psylla and whitefly. Haryana Journal of Horticultural Sciences. 2005; 34(3/4):274

90. Sharma J, Upadhyay AK, Bande D, Patil SD. Susceptibility of Thompson Seedless grapevines raised on different rootstocks to leaf blackening and necrosis under saline irrigation. Journal of plant nutrition. 2011; 34(11):1711-1722

91. Sharma RR, Nagaraja A, Goswami AK, Thakre M, Kumar R, Varghese E et al. Influence of on-the-tree fruit bagging on biotic stresses and postharvest quality of rainy-season crop of 'Allahabad Safeda'guava (Psidium guajava L.). Crop Protection, 2020, 105216.

92. Souza LDP, Nobre RG, Silva EMD, Lima GSD, Pinheiro FW, Almeida LLDS et al. Formation of 'Crioula'guava rootstock under saline water irrigation and nitrogen doses. Revista Brasileira de Engenharia Agrícola e Ambiental. 2016; 20(8):739-745.

93. Souza-Pérez M, Speroni G. New apomictic pathway in Myrtaceae inferred om Psidium cattleyanum female gametophyte ontogeny. Flora (Jena). 2017; 234:34-40

94. Striegler RK, Howell GS. The influence of rootstock on the cold hardiness of Seyval grapevines I. Primary and secondary effects on growth, canopy development, yield, fruit quality and cold hardiness. Vitis. 1991; 30:1-10.

95. Tramontini S, Vitali M, Centioni L, Schubert A, Lovisolo C. Rootstock control of scion response to water stress in grapevine. Environmental and experimental botany. 2013; 93:20-26

96. Troncoso A, Matte C, Cantos M, Lavee S. Evaluation of salt tolerance of in vitro grown grapevine rootstock varieties. Vitis. 1999; 38(2):55-60

97. Tsering Dolkar MA, Banoo A, Slathia D, Stanzen L, Lakdan S. Mitigation of temperate fruit crop problems through use of rootstock. IJCS. 2018; 6(2):880-887

98. Usman M, Samad WA, Fatima B, Shah MH. Pollen parent enhances fruit size and quality in inter-varietal crosses in guava (Psidium guajava). International Journal of Agriculture and Biology. 2013; 15(1):125-129.

99. Valizadeh Kaji B, Abbasifar A, Bagheri H, Zandievakili G, Daryabeigi A. First report: Grafting of Three Iranian Commercial Pomegranate Cultivars on Drought Tolerant Rootstocks. International Journal of Horticultural Science and Technology. 2020; 7(1):69-79.

100.Vos JE, Schoeman MH. In-vitro selection and commercial release of guava wilt resistant rootstock. Acta Hort. 2000; 513:69-79.

101. Walker RR, Blackmore DH, Clingeleffer PR, Correll RL. Rootstock effects on salt tolerance of irrigated field grown grapevines (Vitis vinifera L. cv. Sultana) 2. Ion concentrations in leaves and juice. Australian Journal of Grape and Wine Research. 2004; 10(2):90-99.

102. Walker RR, Kriedemann PE, Maggs DH. Growth, leaf physiology and fruit development in salt-stressed guavas. Australian Journal of Agricultural Research. 1979; 30(3):477-488. 
103. Wheaton TA, Whitney JD, Castle WS, Muraro RP, Browning HW, Tucker DPH et al. Citrus scion and rootstock, topping height and tree spacing affect tree size, yield fruit quality and economic return. J Amer. Soc. Hort. Sci. 1995; 120:861-870.

104.Xiang X, Deng ZA, Chen CX, Gmitter Jr FG, Bowman K. Marker Assisted Selection in Citrus Rootstock Breeding Based on a Major Gene Locus 'Tyr1' Controlling Citrus Nematode Resistance. Agricultural Sciences in China. 2010; 9(4):557-567.

105. Yadava UL. Guava production in Georgia under coldprotection structure. Progress in new crops. ASHS Press, Arlington, VA, 1996, 451-457

106.Zuazo VD, Tarifa DF. Rootstock influence on Fruit Yield, Growth and Mineral Nutrition of Mango (Mangifera indica L. cv. Keitt'). European Journal of Horticultural Science. 2006; 71(3):102. 